\title{
Thermodynamic Study on Production of Fe-Si-Ca Master Alloy Using Modified Molten Converter Slag
}

\author{
Weijun HUANG, Min CHEN*, Lei XU, Jianhong DONG, Nan WANG \\ School of Materials and Metallurgy, Northeastern University, Shenyang, 110189, P. R. China \\ cross $^{\text {ref }}$ http://dx.doi.org/10.5755/j01.ms.21.4.9559
}

Received 23 January 2015; accepted 19 June 2015

\begin{abstract}
The thermodynamic behavior and the effects of energy saving in the production of $\mathrm{Fe}$-Si-Ca master alloy from modified molten converter slag using $\mathrm{SiO}_{2}$ as a modifier were investigated by thermodynamic analysis with different additions of the modifier and reductant at various temperatures to fully recycle the physical sensible heat and valuable elements in the metallurgical slag. The results showed that the activity of $\mathrm{SiO}_{2}$ in the slag increased rapidly with the $w\left(\mathrm{SiO}_{2}\right)$ increase from $40 \mathrm{wt} . \%$ to $60 \mathrm{wt} . \%$, but the activity of $\mathrm{CaO}$ was low and decreased slightly with the $w\left(\mathrm{SiO}_{2}\right)$ increase. When the $w\left(\mathrm{SiO}_{2}\right)$ in the slag was $60 \mathrm{wt} . \%$ with an external addition of $35 \mathrm{wt} . \%$ of reductant at $1800{ }^{\circ} \mathrm{C}$, the reduction ratios of silicon and calcium reached 90.05 mass $\%$ and 52.87 mass \%, respectively, and the $w[\mathrm{Si}]$ and $w[\mathrm{Ca}]$ in the master alloy were $51.60 \mathrm{wt} . \%$ and $17.67 \mathrm{wt} . \%$, respectively, resulting in an energy saving of $805.6 \mathrm{kWh}$ per ton of produced ferroalloys.

Keywords: converter slag, Fe-Si-Ca alloy, molten modification, energy consumption.
\end{abstract}

\section{INTRODUCTION}

In recent years, the diminution and recycling of large amounts of steel slag generated during the steelmaking process has been extensively carried out for both environmental and economical benefits including less slag melting and the secondary utilization of slag. For example, it is recycled as metallurgical materials, agricultural fertilizers, construction materials, and other uses [1-3].

In general, the current utilization of steel slag based on low-value products, and the physical sensible heat carried by the molten slag cannot be well utilized.

Fortunately, several studies have been carried out by taking the valuable elements and physical sensible heat into account for the direct utilization of the molten slag to obtain higher-value products, such as the enrichment of the phosphorus from the slag and the production of Fe-Mn alloy from the slag generated in the Mn-removal treatment of the molten cast iron $[4,5]$.

However, most of the other valuable elements cannot be recycled.

Furthermore, the production of ferroalloys is an energy-consuming and high-pollution industry. Considering that there are plenty of $\mathrm{Ca}$ and $\mathrm{Si}$ elements in molten steel slag as well as their massive physical heat, the present work investigated a novel treatment method for molten steel slag using deep reduction to produce $\mathrm{Fe}-\mathrm{Si}$-Ca master alloy according to the selective reduction principle to cut down on the energy consumption of traditional ferroalloy production [6].

Using the commercial thermodynamic software FactSage 6.2, the thermodynamic behaviors of the components in molten slag during the reduction process and the energy consumption were discussed.

\footnotetext{
* Corresponding author. Tel.: +86-24-63682241; fax: +86-24-83682241. E-mail address: chenm@smm.neu.edu.cn (M. Chen)
}

\section{RAW MATERIALS AND PROCEDURES}

The molten converter slag at $1400{ }^{\circ} \mathrm{C}$ with 17.66 wt. $\%$ $w\left(\mathrm{SiO}_{2}\right)$ shown in Table 1 was used as the raw material, and $\mathrm{SiO}_{2}$ was used as a modifier to adjust the alkalinity of the molten slag [6]. Additionally, carbon powder was selected as a reductant by external addition. Considering that the solution of $\mathrm{SiO}_{2}$ in the converter slag increased from $57.8 \mathrm{wt} . \%$ at $1450{ }^{\circ} \mathrm{C}$ to $78.2 \mathrm{wt} . \%$ at $1750{ }^{\circ} \mathrm{C}$ and the liquidus temperature of the modified slag was below $1600{ }^{\circ} \mathrm{C}$ from $30 \mathrm{wt} \% w\left(\mathrm{SiO}_{2}\right)$ to $60 \mathrm{wt} . \% w\left(\mathrm{SiO}_{2}\right)$, the physical properties of the slag were good with $40-60$ mass $\% \quad w\left(\mathrm{SiO}_{2}\right)$ at temperatures over $1600{ }^{\circ} \mathrm{C}$ $[6,7]$. Therefore, the properties of the modified molten slag and the thermodynamic behaviors were calculated at $1700 \sim 1900{ }^{\circ} \mathrm{C}$ with different amounts of reductant using the Equilib module, Reaction module and Phase Diagram module of FactSage 6.2. The materials balance and heat balance corresponding to $100 \mathrm{~g}$ slag with $60 \mathrm{wt} . \% w\left(\mathrm{SiO}_{2}\right)$ shown in Table 1 were calculated using the View Date module and the Equilib module [8].

\section{RESULTS AND DISCUSSION}

\subsection{Relations between the activity of components and $\mathrm{SiO}_{2}$ content in the slag}

Fig. 1 shows the activity changes of the components in the slag with the $\mathrm{SiO}_{2}$ content at different temperatures under an equilibrium oxygen partial pressure of $21.15 \mathrm{kPa}$. In Fig. 1 a, it can be observed that the activity of the $\mathrm{SiO}_{2}$ was low when its content was small. It started to increase rapidly while the content was over $40 \mathrm{wt} . \%$, and then increased gradually once it was more than $60 \mathrm{wt} . \%$. This result could be due to the fact that while the $\mathrm{SiO}_{2}$ content was lower, it was mainly in the form of $2 \mathrm{CaO} \cdot \mathrm{SiO}_{2}$ in the slag. When the content increased, the $2 \mathrm{CaO} \cdot \mathrm{SiO}_{2}$ 
transformed into the form of $\mathrm{CaO} \cdot(1+x) \mathrm{SiO}_{2}$ and the amount of free $\mathrm{SiO}_{2}$ in the molten slag increased [9, 10].
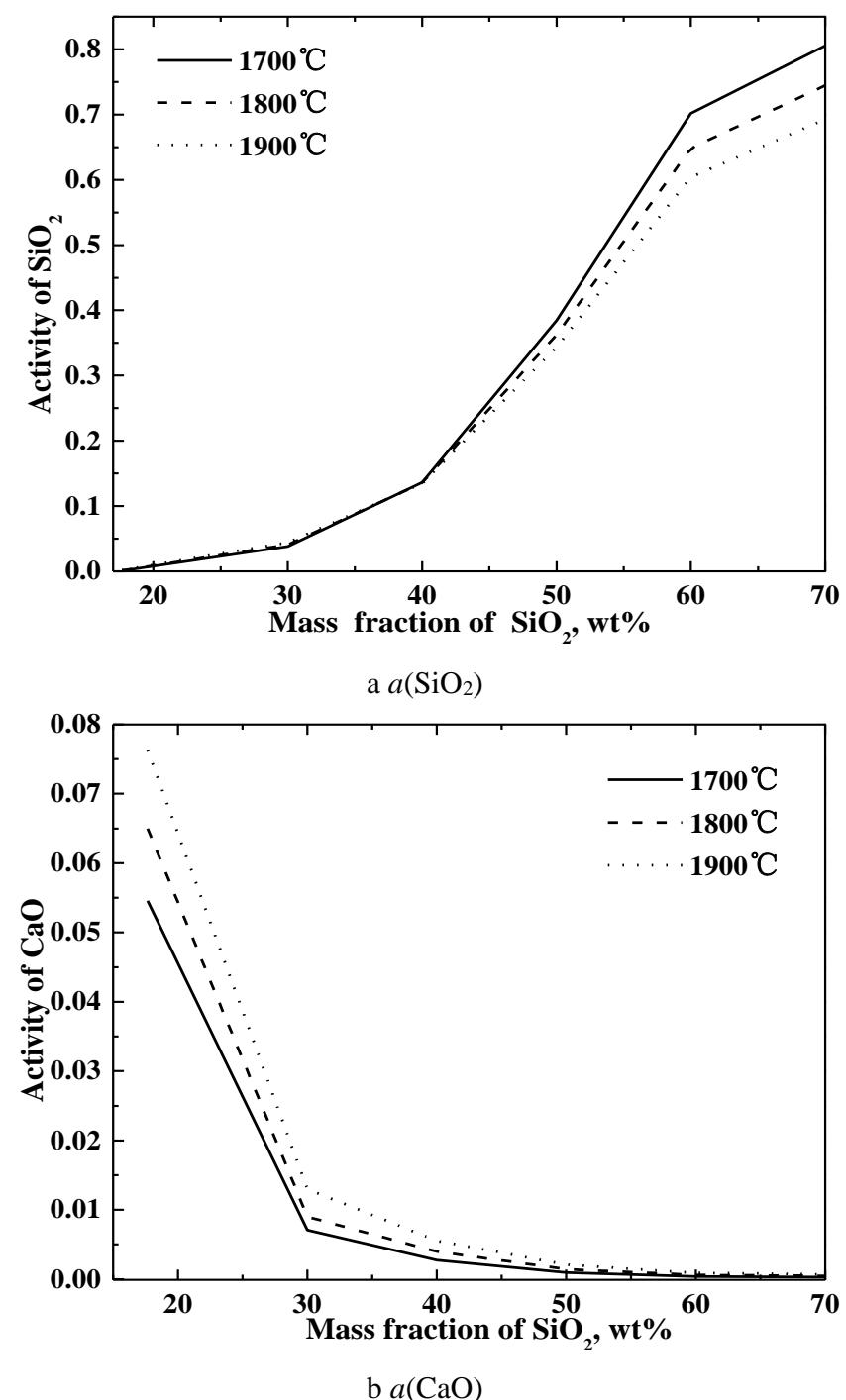

Fig. 1. Relations between activity of components and $\mathrm{SiO}_{2}$ content in the slag at $P_{\mathrm{O}_{2}}=21.15 \mathrm{kPa}$

In addition, it can also be observed in Fig. 1 a that the activity of the $\mathrm{SiO}_{2}$ decreased slightly once the $w\left(\mathrm{SiO}_{2}\right)$ was over $40 \mathrm{wt} \%$ when the temperature increased from $1700{ }^{\circ} \mathrm{C}$ to $1900{ }^{\circ} \mathrm{C}$ due to the occurrence of Reaction (1) to reduce the content of silica in the slag.

$\left(\mathrm{SiO}_{2}\right)=\mathrm{SiO}(\mathrm{g})+1 / 2 \mathrm{O}_{2}(\mathrm{~g})$.

Fig. $1 \mathrm{~b}$ shows the change of activity of the $\mathrm{CaO}$ with the $\mathrm{SiO}_{2}$ content at different temperatures. The activity of the $\mathrm{CaO}$ was very low when the $\mathrm{SiO}_{2}$ content was more than $30 \mathrm{wt} . \%$. This was considered to be due to the large amounts of silica added leading to the dilution of the concentration of calcia and the formation of calcium silicate $\left(\mathrm{CaO} \cdot(1+x) \mathrm{SiO}_{2}\right)$ in the slag. Moreover, when the $\mathrm{SiO}_{2}$ content was over $30 \mathrm{wt} . \%$, the free calcia almost completely turned into complex oxides, and thus its activity was slightly decreased. However, according to the ionic theory [9], silica is an acidic oxide that can strongly attract surrounding $\mathrm{O}^{2-}$ to form covalent silicate anions as a variety of complex silicon-oxygen anions in the slag. At the same time, silicon-oxygen anions further polymerize to form more complex silicon-oxygen compound oxides when the $w\left(\mathrm{SiO}_{2}\right)$ increases. In general, $\mathrm{Ca}^{2+}$ and other cations are located in the cavity among ions, and are in mutual coordination with the non-bridging oxygen to affect the activity of the $\mathrm{CaO}$ in the slag $[10,11]$. When the alkalinity was decreased by increasing the $w\left(\mathrm{SiO}_{2}\right)$, the silicone-oxygen compound oxides further polymerized to consume large amounts of $\mathrm{O}^{2-}$, which increased the $\mathrm{Si}-\mathrm{O}-\mathrm{Si}$ bond, and simultaneously decreased the free $\mathrm{Ca}^{2+}$ $\mathrm{O}^{2-}$ and the activity of the $\mathrm{CaO}$ in the slag. In addition, contrary to the activity of the $\mathrm{SiO}_{2}$, the activity of the $\mathrm{CaO}$ also slightly increased with temperature increases.

\subsection{Metallurgical properties of the modified slag during the reduction process}

Fig. 2 a shows the influence of the $\mathrm{SiO}_{2}$ content on the alloy composition at $1800^{\circ} \mathrm{C}$ with sufficient reductant under the equilibrium carbon monoxide partial pressure of $93.08 \mathrm{kPa}$.
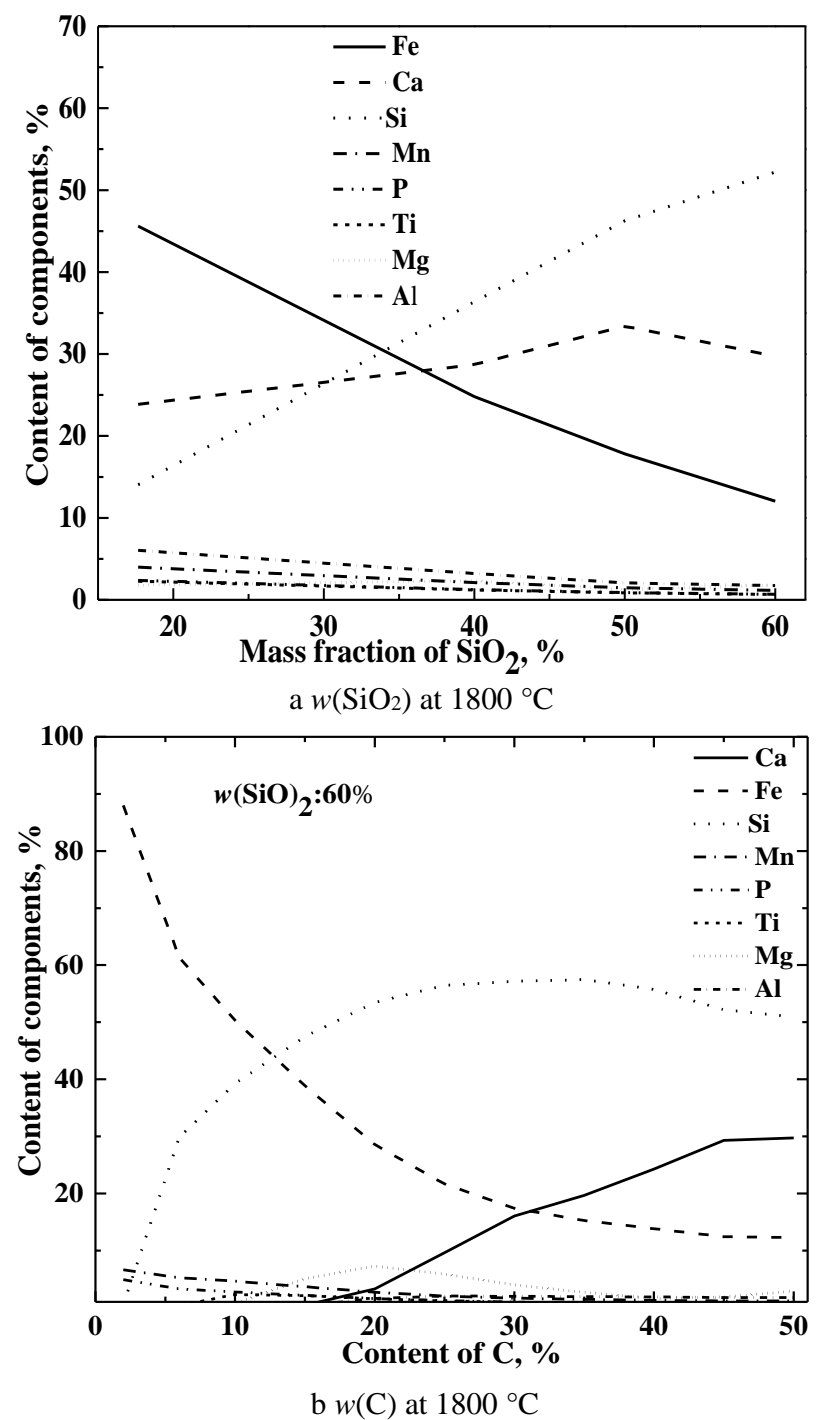

Fig. 2. Influence of the factors on the alloy composition

It was observed that the content of $\mathrm{Si}$ and $\mathrm{Ca}$ in the alloy increased simultaneously with the increase of the content of $\mathrm{SiO}_{2}$ to $50 \mathrm{wt}$.\% due to increase of the activity of the $\mathrm{SiO}_{2}$ (as shown in Fig. 1 a) and the occurrence of Reaction (2) and (3) in the modified slag as the main of 
reaction in the production of $\mathrm{Fe}-\mathrm{Si}-\mathrm{Ca}$ ally at high temprature to increase the content of $\mathrm{Si}$ and $\mathrm{Ca}$ in the metal pool [12]. But a further increase of silica content diluted the concentration of $\mathrm{CaO}$ in the slag and the activity of $\mathrm{CaO}$ was decreased; as a result, the content of $\mathrm{Ca}$ in the alloy was decreased and the content of $\mathrm{Si}$ was further increased gradually when the content of the $\mathrm{SiO}_{2}$ in the modified molten slag was more than $50 \mathrm{wt} . \%$. Therefore, in order to obtain Fe-Si-Ca master alloy with higher levels of silicon and calcium, the content of the $\mathrm{SiO}_{2}$ should be more than $50 \mathrm{wt} \%$ in the modified slag.

$$
1 / 4 \mathrm{SiC}(\mathrm{s})+3 / 8\left(\mathrm{SiO}_{2}\right)+1 / 4(\mathrm{CaO})+3 / 4 \mathrm{C}(\mathrm{s})=
$$$$
=1 / 4 \mathrm{CaSi}(\mathrm{l})+3 / 8 \mathrm{Si}(\mathrm{l})+\mathrm{CO}(\mathrm{g})
$$

$$
\mathrm{CaC}_{2}+2\left(\mathrm{SiO}_{2}\right)-2[\mathrm{C}]=[\mathrm{CaSi}]+[\mathrm{Si}]+4 \mathrm{CO}(\mathrm{g})
$$

Fig. $2 \mathrm{~b}$ shows the change of the composition of the master alloy with different amounts of the added reductant wen the $\mathrm{SiO}_{2}$ content was $60 \mathrm{wt} . \%$. It is known from the thermodynamics analysis that the reduction order of the components in the slag was $\mathrm{FeO}, \mathrm{P}_{2} \mathrm{O}_{5}, \mathrm{MnO}, \mathrm{SiO}_{2}, \mathrm{TiO}_{2}$, $\mathrm{MgO}, \mathrm{Al}_{2} \mathrm{O}_{3}$ and $\mathrm{CaO}[3,6]$. As a result, the content of $\mathrm{Fe}$ in the alloy was maximal while the amount of the added reductant was insufficient, and it decreased gradually with the increase of $\mathrm{Si}$ content in the alloy after the $\mathrm{SiO}_{2}$ in the slag was reduced when the added reductant was more than 2.5 wt.\%. With a further increase of the amount of reductant more than $16 \mathrm{wt} . \%$, the $\mathrm{CaO}$ conten in the slag began to be reduced, resulting in the increase of the $\mathrm{Ca}$ content and decrease of the content of $\mathrm{Fe}$ and $\mathrm{Si}$ in the alloy. But the content of $\mathrm{Ca}$ did not further increased after the amount of reducing agent was more than $45 \mathrm{wt} . \%$. To put it simply, during the reduction process of the modified converter slag, Fe-Si alloy was formed firstly, and then subsequently transformed into Fe-Si-Ca master alloy. To obtain $\mathrm{Fe}-\mathrm{Si}$-Ca master alloy, the proper amount of the reductant should be from $30 \mathrm{wt} . \%$ to $45 \mathrm{wt} . \%$ by external addition.

Fig. 3 shows the influence of temperature on the reduction ratios of the $\mathrm{CaO}$ and $\mathrm{SiO}_{2}$ in the modified slag with various $\mathrm{SiO}_{2}$ contents. Here, the reduction ratio is defined as the mass percentage of the reduced oxides to its original mass in the molten slag. From Fig. 3 a it can be observed that the reduction ratio of the $\mathrm{SiO}_{2}$ climbed quickly with increments of the temperature up to $1800^{\circ} \mathrm{C}$ due to the increase of the $\mathrm{SiO}_{2}$ activity, and it increased slowly with further temperature increasing. For the same reason, as the activity of the $\mathrm{SiO}_{2}$ was dependent on its content, the reduction ratio of the $\mathrm{SiO}_{2}$ was also increased with increments of its content. Similar to the case of the $\mathrm{SiO}_{2}$ reduced, as shown in Fig. 3 b, it was observed that the reduction ratio of the $\mathrm{CaO}$ also increased obviously with increasing temperatures up to $1800{ }^{\circ} \mathrm{C}$ and then increased subtly. In addition, though the activity of the $\mathrm{CaO}$ decreased with the increase of $w\left(\mathrm{SiO}_{2}\right)$ in the slag, as shown in Fig. $1 \mathrm{~b}$, the reduction ratio also obviously increased with the increase of $w\left(\mathrm{SiO}_{2}\right)$ up to $60 \mathrm{wt} . \%$ due to the formation of $\mathrm{CaSi}$ in the alloy by the occurrence of Reaction (2) and (3). A further increase of $w\left(\mathrm{SiO}_{2}\right)$ in the slag showed a smaller effect on the $\mathrm{CaO}$ reduction ratio. From this result, it was also believed that the proper content of $\mathrm{SiO}_{2}$ in the modified converter slag should be up to $60 \mathrm{wt} . \%$ in order to obtain the Fe-Si-Ca master alloy, and the temperature should reach up to $1800{ }^{\circ} \mathrm{C}$ at higher reduction ratios of $\mathrm{CaO}$ and $\mathrm{SiO}_{2}$ in the modified slag.

Fig. $2 \mathrm{~b}$ shows the change of the composition of the master alloy with different amounts of the added reductant wen the $\mathrm{SiO}_{2}$ content was 60 wt. $\%$.

\subsection{The materials balance and the energy consumption}

Table 2 shows the materials balance of the main elements of the modified converter slag with 60 wt.\% $\mathrm{SiO}_{2}$ (see Table 1) after reduced at $1800{ }^{\circ} \mathrm{C}$ by the external addition of appropriate $35 \mathrm{wt} \%$ carbon under the equilibrium carbon monoxide partial pressure of $93.08 \mathrm{kPa}$.

As shown in Table 2, according to the analysis on the composition of the reaction products (including the alloy phase, the slag phase, and the gas phase), the reduction ratios of $\mathrm{CaO}, \mathrm{SiO}_{2}$, and $\mathrm{FeO}$ were $52.87 \%, 90.05 \%$, and $100 \%$, respectively. And at the same time, $45 \mathrm{~g}$ ferroalloy per $100 \mathrm{~g}$ modified slag with contents of $\mathrm{Ca} 19.16$ wt.\% and $\mathrm{Si} 55.94 \mathrm{wt} \%$ was obtained. Calcia and silicon compounds $\left(\mathrm{SiO}_{2}, \mathrm{SiC}\right)$ accounted for $73.04 \mathrm{wt} . \%$ and 26.20 wt. $\%$, respectively, in the final slag. CO with a content of more than $90 \mathrm{wt}$.\% was the main gas phase.

In order to analyze further energy consumption, Table 3 shows the heat balance of $100 \mathrm{~g}$ of the modified converter slag and the pure compounds with $60 \mathrm{wt} . \% \mathrm{SiO}_{2}$ (as shown in Table 1) at $1800{ }^{\circ} \mathrm{C}$ by the external addition of the appropriate $35 \mathrm{wt} . \%$ carbon under the equilibrium carbon monoxide partial pressure of $93.08 \mathrm{kPa}$ slag.

On the bases of actual production conditions and convenient calculation, the reduction ratios of silica, calcia, and ferrous oxide were $90.05 \%, 52.87 \%, 100 \%$, respectively, by the traditional technology using the pure compounds [12]. It could be seen that the heat income included the physical sensible heat of the slag, chemical heat by the formation of $\mathrm{CaSi}$ and $\mathrm{FeSi}$ in the metal, and the slag forming heat from the formation of $\mathrm{CaO} \cdot(1+x) \mathrm{SiO}_{2}$.

Heat expenditure also included the oxide chemical heat for the reduction of the oxides in the slag, the physical heat for heating the carbon, modifier (silica) from room temperature to $1800{ }^{\circ} \mathrm{C}$, the physical heat for heating the molten slag from $1400{ }^{\circ} \mathrm{C}$ to $1800{ }^{\circ} \mathrm{C}$, and the physical heat carried by the formed gas phase, alloy phase, and slag phase.

Compared to the modified slag and the pure compounds, there was not physical sensible heat carried by the molten slag in the mixed pure oxides reduced in the same conditions, as shown in Table 3 . Meanwhile, the energy consumption was $1228.1 \mathrm{~kJ}$ for the reduction of the modified slag, and $1283.0 \mathrm{~kJ}$ for the reduction of the mixed pure oxides. In addition, the heat income was $123.4 \mathrm{~kJ}$ for the reduction of the modified slag, and it was $48.4 \mathrm{~kJ}$ for the mixed pure oxides reduced. The results indicated that energy consumption was $1104.7 \mathrm{~kJ}$ under $100 \mathrm{~g}$ modified slag condition, which was lower than $1234.6 \mathrm{~kJ}$ under $100 \mathrm{~g}$ pure compounds condition.

Table 2 and Table 3 illustrate that $0.13 \times 10^{7} \mathrm{~kJ}$ energy could be saved in the production of 0.45 ton ferroalloy 
using 1 ton modified steel slag with 60 wt. $\% \quad \mathrm{SiO}_{2}$ compared to that of the mixed oxides, corresponding to save $0.29 \times 10^{7} \mathrm{~kJ}$ energy in the production of per ton ferroalloy, amounting to $805.6 \mathrm{kWh}$ per ton ferroalloy. Thus, it is considered that the modification treatment and deep reduction of converter slag is an effective method to recycle valuable elements in the metallurgical slag.
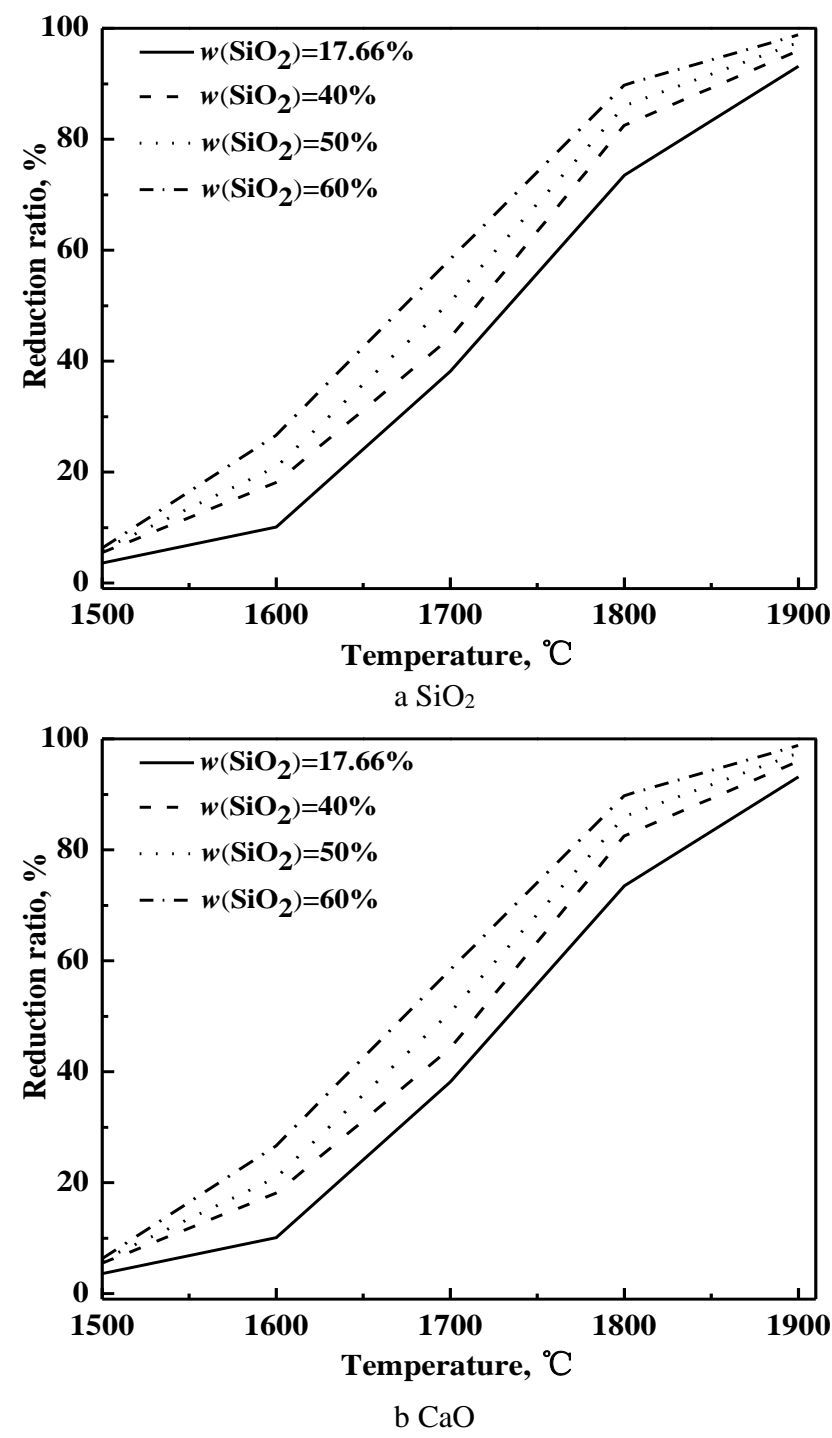

Fig. 3. Reduction ratios of $\mathrm{CaO}$ and $\mathrm{SiO}_{2}$ at various temperatures

\section{CONCLUSIONS}

A thermodynamic study on physical sensible heat and valuable elements recycling from the molten converter slag using $\mathrm{SiO}_{2}$ as a modifier by deep reduction was carried out on the production of $\mathrm{Fe}-\mathrm{Si}-\mathrm{Ca}$ master alloy, and the following conclusions could be drawn.

1. The activity of $\mathrm{SiO}_{2}$ in the slag system increased rapidly when its content increased from $40 \mathrm{wt} \%$ to $60 \mathrm{wt} . \%$, and then increased gradually with additional increments of $w\left(\mathrm{SiO}_{2}\right)$. Meanwhile, the activity of $\mathrm{CaO}$ was low and decreased slightly with the increase of $w\left(\mathrm{SiO}_{2}\right)$.

2. The reduction order of the components in the modified slag was $\mathrm{FeO}, \mathrm{P}_{2} \mathrm{O}_{5}, \mathrm{MnO}, \mathrm{SiO}_{2}, \mathrm{TiO}_{2}, \mathrm{MgO}, \mathrm{Al}_{2} \mathrm{O}_{3}$ and $\mathrm{CaO}$. In a word, during the reduction process of the modified converter slag, Fe-Si master alloy was formed initially, and was subsequently transformed into Fe-Si-Ca master alloy.

3. The reduction ratios of the $\mathrm{SiO}_{2}$ and $\mathrm{CaO}$ climbed quickly with increments of temperature up to $1800{ }^{\circ} \mathrm{C}$, and then increased subtly with further increase of temperature. The contents of $\mathrm{Si}$ and $\mathrm{Ca}$ in the alloy began to increase when the amount of the reducing agent was more than $2.5 \mathrm{wt} . \%$ and $16 \mathrm{wt} . \%$ respectively, but it did not further increase after the amount of the reducing agent was more than $45 \mathrm{wt} . \%$.

4. When the $w\left(\mathrm{SiO}_{2}\right)$ in the modified slag was $60 \mathrm{wt} . \%$ with $35 \mathrm{wt} . \%$ reductant added at $1800{ }^{\circ} \mathrm{C}$, the reduction ratios of the $\mathrm{CaO}$ and $\mathrm{SiO}_{2}$ reached $52.87 \mathrm{wt} . \%$ and 90.05 wt.\%, respectively, which could save approximately $805.6 \mathrm{kWh}$ of energy per ton of ferroalloy produced compared to using mixed pure oxides.

\section{Acknowledgement}

The authors gratefully acknowledge the National Natural Science Foundation of China (No. 51174049, 51174052, 51374057, 51374062) and the Fundamental Research Funds for the Central Universities of China (No.120402005) which has made this research possible.

Table 2. Materials allocation sheet after reaction for $60 \% \mathrm{SiO}_{2}$ at $1800{ }^{\circ} \mathrm{C}\left(P_{\mathrm{CO}}=93.08 \mathrm{kPa}\right)$

\begin{tabular}{|c|c|c|c|c|c|c|c|}
\hline \multirow{2}{*}{$\begin{array}{c}\text { Component } \\
\text { ingredient }\end{array}$} & \multicolumn{2}{|c|}{ The metal phase } & \multicolumn{2}{c|}{ The slag phase } & \multicolumn{2}{c|}{ The gas phase } & Total \\
\cline { 2 - 8 } & Mass, g & $\begin{array}{c}\text { Percentage, } \\
\text { wt. } \%\end{array}$ & Mass, g & $\begin{array}{c}\text { Percentage, } \\
\text { wt. } \%\end{array}$ & Mass, g & $\begin{array}{c}\text { Percentage, } \\
\text { wt.\% }\end{array}$ & Mass, g \\
\hline $\mathrm{SiO}_{2}$ & 54.081 & 90.048 & 1.521 & 2.533 & & & \\
\hline $\mathrm{SiC}$ & & & 2.398 & 3.990 & & & \multirow{2}{*}{60.058} \\
\hline $\mathrm{SiO}$ & & & & & 2.058 & 3.427 & 22.889 \\
\hline $\mathrm{CaO}$ & 12.102 & 52.873 & 10.329 & 45.127 & 0.459 & 2.005 & 8.583 \\
\hline $\mathrm{FeO}$ & 8.583 & 100.000 & 0.000 & 0.000 & 0.000 & 0.000 & 34.972 \\
\hline $\mathrm{C}$ & 1.006 & 2.877 & & & & & \\
\hline $\mathrm{CO}$ & & & & & 33.246 & 95.065 & \\
\hline $\mathrm{SiC}$ & & & 0.719 & 2.059 & & & \\
\hline
\end{tabular}


Table 3. Energy balance sheet of heat at $1800{ }^{\circ} \mathrm{C}\left(P_{\mathrm{CO}}=93.08 \mathrm{kPa}\right)$

\begin{tabular}{|c|c|c|c|c|c|}
\hline \multicolumn{2}{|c|}{ Income items } & \multicolumn{3}{c|}{ Expenditure items } \\
\hline Item & $\begin{array}{c}\text { Modified } \\
\text { slag, J }\end{array}$ & $\begin{array}{c}\text { Pure } \\
\text { compounds, J }\end{array}$ & $\begin{array}{c}\text { Modified } \\
\text { slag, J }\end{array}$ & $\begin{array}{c}\text { Pure } \\
\text { compounds, J }\end{array}$ \\
\hline $\begin{array}{c}\text { Physical sensible } \\
\text { heat of the slag }\end{array}$ & 84828.4 & 0 & $\begin{array}{c}\text { Oxides chemical heat } \\
\text { for reduction of oxides }\end{array}$ & 715891.8 & 675896.6 \\
\hline $\begin{array}{c}\text { Chemical heat by the } \\
\text { formation of CaSi } \\
\text { and FeSi in the metal }\end{array}$ & 28489.6 & 28259.6 & $\begin{array}{c}\text { Physical heat for } \\
\text { heating reactants }\end{array}$ & 209748.8 & 294577.2 \\
\hline $\begin{array}{c}\text { The slag forming } \\
\text { heat by formation } \\
\text { Of } \mathrm{CaO}(1+x) \mathrm{SiO}_{2}\end{array}$ & 10032.2 & 20122.2 & $\begin{array}{c}\text { Physical heat carried by } \\
\text { the formed the reaction } \\
\text { products }\end{array}$ & 302497.5 & 312507.5 \\
\hline Total & 123350.2 & 48381.8 & Total & 1228138.1 & 1282981.3 \\
\hline
\end{tabular}

\section{REFERENCES}

1. Arqenta, P., Guzzon, M. Techint's Latest Developments in EAF Environmental-Friendly Technologies Steel Times International 30 (6) 2006: pp. $49-51$.

2. Leasdale, T.S., Hayes, P.C. Observation of the Reduction of $\mathrm{FeO}$ from Slag by Graphite, Coke and Coal Char ISIJ International $45(5) \quad 2005: \quad$ pp. 634-641. http://dx.doi.org/10.2355/isijinternational.45.634

3. Ye, Z.G., Burstrom, E., Kuhn, M., Piret, J. Reduction of Steelmaking Slags for Recovery of Valuable Metals and Oxide Materials Scandinavian. Journal of Metallurgy 32 (1) 2003: pp. $7-14$.

4. Takawa, T., Ueda, S., Ike, H., Iwashimizu, K., Inoue, R. Production of Mn-Fe Alloy from Slag Generated in MnRemoval Treatment of Molten Cast Iron ISIJ Internatioal 49 (11) 2009: pp. 1673 - 1677.

5. Yang, X., Matsuura, H., Tsukihashi, F. Condensation of $\mathrm{P}_{2} \mathrm{O}_{5}$ at the Interface Between $2 \mathrm{CaO} \cdot \mathrm{SiO}_{2}$ and $\mathrm{CaO}-\mathrm{SiO}_{2}-$ $\mathrm{FeO} x-\mathrm{P}_{2} \mathrm{O}_{5}$ Slag ISIJ International 49 (9) 2009: pp. $1298-1307$. http://dx.doi.org/10.2355/isijinternational.49.1298

6. Tian, Z., Yu, Q.X., Chen, M. Thermodynamic Study on Production of Fe-Si-Mn Alloy From Adjusted
Converter Slag Advanced Materials Research 295 2011: pp. $2290-2293$.

http://dx.doi.org/10.4028/www.scientific.net/AMR.295-297.2290

7. Lee, Y.E., Gaskell, D.R. The Densities and Structures of Melts in the System $\mathrm{CaO}-\mathrm{FeO}-\mathrm{SiO}_{2}$ Metallurgical and Materials Transactions B 5B 1974: pp. 853-860. http://dx.doi.org/10.1007/bf02643138

8. Bale, C.W., Chartrand, P., Degterov, S.A. Factsage Thermochemical Software and Database Calphad $26(2)$ 2002: pp. $189-228$.

9. Hiroki, O., Hideaki, S. Activities of $\mathrm{SiO}_{2}$ and $\mathrm{Al}_{2} \mathrm{O}_{3}$ Activity Coefficients of $\mathrm{Fe}_{\mathrm{t}} \mathrm{O}$ and $\mathrm{MnO}$ in $\mathrm{CaO}-\mathrm{SiO}_{2}-\mathrm{Al}_{2} \mathrm{O}_{3}-$ $\mathrm{MgO}$ Slags Metallurgical and Materials Transactions $B$ 29 (1) 1998: pp. 119 - 129. http://dx.doi.org/10.1007/s11663-998-0014-1

10. Taniguchi, Y., Morita, K., Sano, N. Activity of $\mathrm{FeO}$ in $\mathrm{CaO}-\mathrm{SiO}_{2}-\mathrm{Al}_{2} \mathrm{O}_{3}-\mathrm{FeO}$ and $\mathrm{CaO}-\mathrm{Al}_{2} \mathrm{O}_{3}-\mathrm{CaF}_{2}-\mathrm{FeO}$ Slag ISIJ Internatioal 37 (4) 1997: pp. $956-961$.

11. Ohta, H., Suito, H. Activities in $\mathrm{CaO}-\mathrm{MgO}-\mathrm{Al}_{2} \mathrm{O}_{3}$ Slags and Deoxidation Equilibria of $\mathrm{Al}, \mathrm{Mg}$, and $\mathrm{Ca}$ ISIJ International 36 (8) 1996: pp. 983 - 990. http://dx.doi.org/10.2355/isijinternational.36.983

12. XU, C.C. Ferroalloy Smelting Technology, Metallurgical industry Press, Beijing 2008: pp. $72-80$. 